Sławomir Bralewski (Łódź)

(iD) https://orcid.org/0000-0002-4708-0103

\title{
Was Constantine the Great Aware of The Constantinian Shift?
}

\begin{abstract}
A ccording to Christian authors, the birth of Christ - Salvator mundi - coincided with a fundamental shift in the history of the world. Already during the late antiquity, it was being stressed that Christ was born as a human being and a Roman citizen during the reign of Augustus, who ordered the closing of the doors of the temple of Janus and brought peace on earth - the Pax Augusta ${ }^{1}$. According to the Christian narrative, the Emperor, through an internal re-organisation of the Roman Empire, unknowingly prepared the country for the coming of Christ, facilitated the spread of Christianity, and thus unwittingly played an important role in the aforementioned plan, contributing to the creation of the community of all people. Peace was to become the foundation of the new order in the world and was related to the birth of Christ-God, who was its true source, and who, through his earthly revelation, was considered the true founder of this new order, and the bringer of peace ${ }^{2}$.

Thus, the Pax Romana, or the Pax Augusta, became, according to Christian authors, the pax Christiana ${ }^{3}$. However, the fight against God ( $\left.\theta \varepsilon o \mu a x i ́ a\right)$ initiated
\end{abstract}

\footnotetext{
${ }^{1}$ Augustus, by introducing monarchy, and, as a consequence, the pax Augusta, provided Imperium Romanum with stabilization on an unprecedented scale. The success achieved by this ruler influenced the political views of Eusebius of Caesarea, who treated the "divine monarchy" as the best of all political orders. See Eusebius, Demonstratio evangelica, III, 2, 27, ed. I.A. Heikel, Leipzig 1913 [= GCS, 23] (cetera: Demonstratio evangelica). See also A. KotŁowsкA, Obraz dziejów w Chronici Canones Euzebiusza z Cezarei, Poznań 2009, p. 204-206.

${ }^{2}$ For example, Origen of Alexandria (Contra Celsum, II, 30, ed. M. Marcovich, Leiden 2001, p. 107) indicated that Octavian August united many peoples of the earth in one kingdom, which brought global peace necessary for Christ's teaching to triumph. Thus, according to Origen, God, through Augustus, created proper conditions for the free spread of the Gospel.

${ }^{3}$ Eusebius of Caesarea (Eusèbe DE CÉsARÉE, La préparation évangélique, I, 4, vol. I-IV, ed. et trans. E. DEs Places, Paris 1976-1987; Demonstratio evangelica, III, 7, 30; VII, 2, 22; VIII, 3; VIII, 4, 12; IX, 17, 13) treats the pax Augusta as a work of Divine Providence predicted in the Old Testament. In Divinae Institutiones (LACTANCE, Institutions Divines. Livre V, V, 5-8, vol. I-II, ed. et trans.
} 
by mankind did not cease ${ }^{4}$. Eusebius of Caesarea, a Christian erudite and a biographer of Emperor Constantine, believed that it was being fought, among others, by the persecutors of Christians, who acted as if they were capable of defeating God

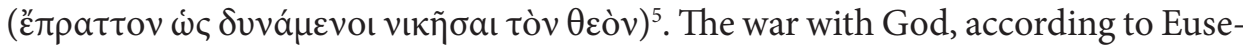
bius, was only concluded with the military victories of Constantine and his sons,

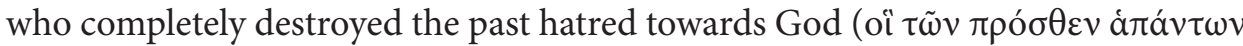

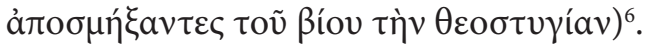

According to the Christian authors of late antiquity, Constantine brought an end to the persecutions of Christians and restored peace ${ }^{7}$. Therefore, his role in God's plan for the world was seen as extremely important. Furthermore, Constantine, through the protection he extended over the believers of Christ, was to have begun a new era of eschatological Kingdom of God on earth and opened a new chapter in the history of humanity, leading people towards unity, which had its origins in the One $\mathrm{God}^{8}$. Paul Orosius, a theologian and a Christian historian from the late $4^{\text {th }}$ and early $5^{\text {th }}$ centuries, wrote about One God, one Emperor, one Empire, one Church, one peace, one fatherland, one law, one faith'.

P. Monat, Paris 1973 [= SC, 204-205]), written before the year 313, Lactantius wrote about a golden age when the worship of one God was dominant, resulting in peace and common harmony. Lactantius was convinced that Christianity, the Religion of the Most High God, is the original and natural religion of all mankind. See L.J. SwIFT, Lactantius and the Golden Age, AJP 89, 1968, p. 144-156; V. Buchneit, Goldene Zeit und Paradies auf Erden (Laktanz, Inst. 5,5-8), WJA 4, 1978, p. 161-185 and 5, 1979, p. 219-235; O. Nicholson, Golden Age and the End of the World: Myths of Mediterranean Life from Lactantius to Joshua the Stylite, [in:] The Mediaeval Mediterranean, ed. M. CHIAT, K. Reyerson, S. Cloud, Minnesota 1989, p. 11-18.

${ }^{4}$ Euzebiusz z Cezarei, Historia kościelna, I, 2, 19, trans. A. Caba, ed. H. Pietras, Kraków 2013 (cetera: Eusebius, $H E$ ).

${ }^{5}$ Eusebius, $H E, \mathrm{~V}, 1,63$. Apparently, the war against God was also waged by Licinius, who ordered the persecution of Christians; see Eusebius, Vita Constantini, II, 1, ed. F. Winkelmann, Berlin-New York 2008 (cetera: Eusebius, Vita Constantini).

${ }^{6}$ Eusebius, HE, X, 9, 9; see also Eusebius, Vita Constantini, I, 3; I, 5.

${ }^{7}$ Eusebius, Chronicon - year 313 (Romanorum 34, regnavit Constantinus 10), [in:] Eusebius, Werke, vol. VII, Die Chronik des Hieronymus, ed. R. HeLm, Berlin 1956 [= GCS, 47], 230c: Pax nostris a Constantino reddita. For Eusebius, peace was restored, not granted, by Constantine. The world was returning to its normal state after the persecutions of Christians. See A. KотєowsKA, Obraz

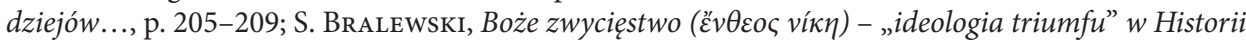
kościelnej Euzebiusza z Cezarei, VP 35, 2015, p. 349-350.

${ }^{8}$ See R. Kühschelm, Nowy Testament, [in:] K. Koenen, R. Kühschelm, Przełom czasów z perspektywy Starego i Nowego Testamentu, trans. J. Zrchowicz, Kraków 2001, p. 87-92. On the subject of the Biblical idea of the Kingdom of God and the associated idea of Yahweh's kingship, see T. NAwRACA£A, Gdzie jest basileia? Biblijne, historyczne i teologiczne aspekty wspótczesnej dyskusji na temat królestwa Bożego, PST 25, 2011, p. 174-182.

${ }^{9}$ Orose, Histoires (Contre les Païens), III, 8, 5; V, 2, 1; VII, 33, 17-19, vol. I-II, ed. et trans. M.-P. ARNAUd-Lindet, Paris 1990-1991. See also K. ILsKi, Idea jedności politycznej społecznej i religijnej w świetle pism Ambrożego z Mediolanu, Poznań 2001, p. 224. 
In modern historiography, the Constantinian shift is discussed rather frequently, in the context of Constantine's conversion to Christianity and the consequences this decision had ${ }^{10}$. In this context, attention is given primarily to his implementation of the Roman Empire's new policy towards Christianity, which a few decades later became the religion of the Roman state. For Constantine not only proclaimed tolerance towards the believers in Christ, but also entered into a special relationship with the God of Christians. It could be defined as a sort of symmachy, which at first had a mostly military dimension, and which in time transformed into a close association of the Empire and the institutional organisation of Christians that was the Church ${ }^{11}$. From the times of Constantine the Great, it enjoyed numerous privileges. This relationship was characterised as unbreakable by Theodosius II in a letter calling bishops to the proceedings in Ephesus in $431^{12}$. Some historians think that during the so-called period of the Little Peace of the Church, in the latter half of the $3^{\text {rd }}$ century, Christianisation had already made sufficient progress and could no longer have been stopped, and because of this they do not see Constantine's reign as a shift in this respect ${ }^{13}$. It would appear, however,

\footnotetext{
${ }^{10}$ See J. Vogt, Die Revolution Constantins des Grossen, [in:] Constantin der Grosse und sein Jahrhundert, München 1960, p. 135-256; Die Kirche Angesichts der Konstantinischen Wende, ed. G. RuHBACH, Darmstadt 1976; R. FARIna, Eusebio di Cesarea e la „Svolta Costantiniana”, Aug 26, 1986, p. 313-322; J. BleICKen, Constantin der Grosse und die Christen. Überlegungen zur konstantinischen Wende, München 1992; Die konstantinische Wende, ed. E. Müchlenberg, Gütersloh 1998; G. BonAMENTE, La „svolta constantiniana”, [in:] Cristianesimo e istituzioni politiche. Da Augusto a Guistiniano, ed. E. Dal Covolo, R. Uglione, Roma 2001, p. 147-170; K.M. Girardet, Die Konstantinische Wende. Voraussetzungen und geistige Grundlagen der Religionspolitik Konstantins des Grossen, Darmstadt 2006, p. 39-155; Konstantin der Grosse. Kaiser einer Epochenwende, ed. F. Schuller, H. WolfF, München 2007; J. Rist, Constantin et l'Église. Remarques sur le soi-disant tournant constantinien, CPE 109, 2008, p. 43-55; R. VAN DAM, The Roman Revolution of Constantine, Cambridge 2007; F. CaRLÀ, M.G. Castello, Questioni tardoantiche. Storia e mito della svolta costantiniana, Roma 2010; S. BRALEWski, Przełom konstantyński a religijność Rzymian w wiekach IV i V - wybrane zagadnienia, [in:] Bitwa przy moście mulwijskim. Konsekwencje, ed. Z. Kalinowski, D. Próchniak, Poznań 2013, p. 115-149; IDEM, Constantinian Shift - the Truth or a Myth, VP 34, 2014, p. 39-53. As emphasized by Noel Lenski (Constantine and the Cities. Imperial Authority and Civic Politics, Philadelphia 2016, p. 27), Constantine's life story, in his own words, was one of conversion, effected directly by divine intervention, which transformed him from an unbeliever to a believer.

${ }^{11}$ S. BRAlewski, Symmachia Cesarstwa Rzymskiego z Bogiem chrześcijan (IV-VI wiek), vol. I, „Niezwykła przemiana" - narodziny nowej epoki, vol. II, Jedna religia w jednym cesarstwie. Rzymscy imperatorzy sprzymierzeni z Bogiem na straży jedności Kościoła od Konstantyna I do Justyniana I, Łódź 2018 [= BL, 27; 32].

${ }^{12}$ Acta Conciliorum Oecumenicorum, ed. E. Schwartz (cetera: ACO), vol. I, Concilium Universale Ephesenum, 1, 1, Berolini-Lipsiae 1927, p. 114-115.

${ }^{13}$ Views in this spirit were formulated, among others, by: W.H.C. Frend, Martyrdom and Persecution in the Early Church. A Study of a Conflict from the Maccabees to Donatus, Oxford 1965, p. 440-476; P. Brown, The World of Late Antiquity, London 1971, p. 60-65; F. Millar, The Emperor in the Roman World 31 B.C.-A.D. 337, London 1977, p. 551sqq; T.D. BARNES, Constantine and
} 
that it was not an increase in the number of the worshippers of Christ that constituted a breakthrough, but the alliance of Constantine with the God of Christians, who became the patron of this Emperor and also, with the sole exception of Julian the Apostate, of his successors. This is because it was said alliance that led to the close relationship between the Imperium Romanum and the Church.

However, a question arises of whether Constantine himself was aware of the revolution that he was carrying out. Did he realise that his actions were going to change the course of the history of the Empire? Among those subscribing to this point of view was Hermias Sozomen in the mid- $5^{\text {th }}$ century, who pointed to the great and wondrous transformation of the world through God's will, which resulted in the abandonment of both the former religion and native traditions ${ }^{14}$. An affirmative response to questions thus asked raises further queries: what did the ruler himself consider the shift to have been? Did he see it, like the contemporary historiography, in his conversion to Christianity?

The question of Constantine's support for Christianity is a highly complex one $^{15}$. Prior to his association with the God of Christians, Constantine was seeking divine protectors among the gods popular at the time in Imperium Romanum. His zeal in doing so was the greater, it would seem, the less stable his position was within the Empire. This is clearly visible after 305, when, after Diocletian's and Maximian's abdications, Galerius became the first Augustus, and Constantine was not considered when the positions of Caesars were being conferred. This placed him in a very difficult situation, which became even worse with the death of his father, Constantius I. The young ruler was constantly forced to face the ever new threats, whether from Galerius, or from Maximian and Maxentius. Raised in the Roman religious tradition, he sought a mighty divine protector all the more eagerly. Later, he most often referred to that patron as the Highest God (Summus Deus), who, through his protection, was to ensure Constantine's military victories over internal and external foes. At first, the ruler saw his patron in Mars, to whom Galerius's victory over the Persians was ascribed. However, when Galerius's war successes ceased, and Mars became the patron deity of Maxentius, who was hostile towards Constantine, the latter first found a divine patron in Sol Invictus, only to soon afterwards, even before the decisive confrontation by the Milvian Bridge,

Eusebius, Cambridge Mass.-London 1981, passim; IDEM, Christians and Pagans in the Reign of Constantius, [in:] L'Église et l'Empire au IV siècle, ed. A. Dihle, Genève 1989, p. 306-310. It should be remembered, however, that, although the Christianization of the inhabitants of the empire had been progressing for over two centuries, at the beginning of the fourth century Christians were in a decided minority. In addition, the process was uneven, leading to large disproportions between the poorly Christianised West and the much better Christianised East (cf. Le problème de la christianisation du monde antique, ed. H. Inglebert, S. Destephen, B. Dumézil, Paris 2010, passim).

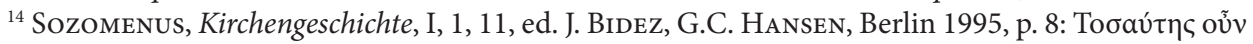

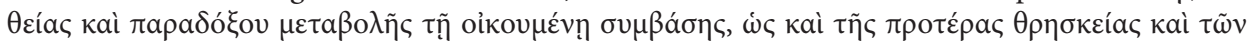
$\pi \alpha \tau \rho i ́ \omega v$ vó $\mu \omega v$ ả $\mu \varepsilon \lambda \tilde{\eta} \sigma \alpha$.

${ }^{15}$ There is extensive literature on this issue, see S. Bralewski, Symmachia..., vol. I, p. 25-81. 
recognise Christ as his protector, and it was Christ to whom he ascribed his military victories. Besides, it would appear that, like many of his contemporaries, he identified the aforementioned solar deity with $\mathrm{Christ}^{16}$. If one were to see Constantine's conversion to Christianity in this manner, then the campaign against Maxentius in 312 was not a breakthrough in this regard, since at the time Constantine only identified the Highest God (Summus Deus), whom he had already worshipped, with Christ ${ }^{17}$. It seems that Constantine's father, Constantius I, was also a worshipper of Summus Deus, and apparently this was the reason why Eusebius of Caesarea was suggesting his inclinations towards Christianity ${ }^{18}$.

Therefore, was Constantine aware of the Constantinian shift, and if so, how did he understand it? In the speech given at the inauguration of the proceedings of the Council of Nicaea (June 325) ${ }^{19}$, and therefore already after he had united the entirety of the Imperium Romanum under his rule, Constantine mentioned the joy shared with those who, thanks to God working through him, had regained their freedom ${ }^{20}$. He argued that they had been freed by God's will and with God's help, which saw his victory over his enemies, and for that the ruler thanked God ${ }^{21}$, calling Him their mutual Lord and Saviour. Constantine referred

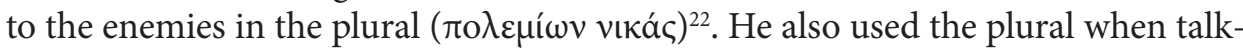
ing about the overthrown tyrants who were fighting against God ( $\tau \tilde{\omega} v \tau v \rho a ́ v v \omega v$

\footnotetext{
${ }^{16}$ See M. Wallraf, Christus Verus Sol. Sonnenverehrung und Christentum in der Spätantike, Münster 2001, p. 126-143.

${ }^{17}$ See S. Bralewski, Symmachia..., vol. I, p. 26-69.

${ }^{18}$ Eusebius of Casesarea (Vita Constantini, I, 27, 2) claimed that Constantius worshipped the God of the universe (ö $\lambda \omega v \theta \varepsilon$ co $)$ ), whom he considered a Saviour and Guardian of the Empire, and the Dispenser of all good. In Church history (VIII, 13, 12), Eusebius wrote, in turn, of Constantius' preference for the Word of God. According to Socrates of Constantinople (Socrates, Kirchengeschichte, I, 2, 3, ed. G.C. Hansen, Berlin 1995) Constantius abandoned the Hellenic (pagan) beliefs, thanks to which he was happier in life. According to T.G. Elliott (Constantine's Conversion: Do We Really Need It?, Phoe 41, 1987, p. 420-438), Constantine's conversion to Christianity took place as early as during his stay in Britain, i.e. around 303. Klaus Martin GIRARDET was another supporter of the view that Constantine converted to Christianity early (Die Konstantinische Wende..., p. 41-155). Paulinus of Nola (Epistulae, XXXI, 4, ed. G. De Hartel, Wien 1894 [= CSEL]) pointed to Helena, the mother of Constantine, as the one who led him to Christianity. Constantine's half-sister, daughter of his father Constantius and Theodora, was named Anastasia, which may be evidence of the family's association with Christianity (Ammianus MARCELlinus, Rerum gestarum libri qui supersunt, XXVI, 6, 14, vol. I-II, ed. C.V. Clark, Berlin 1910-1915). Bertrand LançON and Tiphaine Moreau (Constantin. Un Auguste chrétien, Paris 2012, p. 42) concluded that la conversion de Constantin trouve ses origines dans le cercle familial.

${ }^{19}$ The council was most likely inaugurated in June; see Epistula Constantini imperatoris ad episcopos (syriace), [in:] Athanasius, Werke, vol. III, ed. H.G. von Opitz, Leipzig-Berlin 1934, p. 41-42; ACO, vol. II, Concilium Universale Chalcedonense, 3, 2, Berolini-Lipsiae 1936, p. 264; cf. H. Pietras, Sobór Nicejski (325). Kontekst religijny i polityczny, dokumenty, komentarze, Kraków 2013, p. 137-138.

${ }^{20}$ Eusebius, Vita Constantini, III, 12, 3, p. 87.

${ }^{21}$ Eusebius, Vita Constantini, III, 12, 3, p. 87.

${ }^{22}$ Eusebius, Vita Constantini, III, 12, 3, p. 87.
} 
$\theta \varepsilon$ ouaxíac) $)^{23}$. The remark about tyrants suggests that the passage was not referring to victories over barbarians ${ }^{24}$, but over internal enemies. The plural indicates that, although the Emperor was delivering the speech several months after defeating Licinius (autumn of 324), he most likely had in mind not only the latter, but also the previously defeated Maxentius (autumn 312). Thus, he classified both as enemies of God, and ascribed the victories over them to God's intervention. Likewise, in the speech to the assembly of the saints, Constantine expressed gratitude to God for the attained victories and the trophies taken from the enemies ${ }^{25}$. In a letter addressed to Alexander, the bishop of Alexandria, and his presbyter Arius, Constantine wrote about the overthrown baleful tyranny, which he also referred to

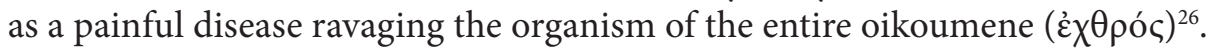

Who, then, were those freed from the tyranny's yoke? Without doubt, they were Christians. In a letter to Shapur, the King of the Persians, Constantine was writing about himself as a witness of a sad end of those who until recently had tormented the people dedicated to God through ungodly decrees, referring to the great persecution of Christians initiated by Diocletian and Galerius. It would seem, however, that in his arguments the ruler meant not only Christians, but all the inhabitants of the Empire, since they had all been suffering under the yoke of the tyrants fighting against God. This can be clearly seen in an earlier part of the aforementioned letter ${ }^{27}$. Constantine directly wrote that he had freed from the power of the tyrants the entire oikoumene, giving its inhabitants the hope for salvation. Therefore, the Emperor clearly thought of all of the inhabitants of the Roman Empire as the beneficiaries of his activities against the tyrants. Now, they could enjoy not only physical freedom and a temporal salvation, but also, thanks to the divine Patron of the Emperor, they were given a chance for eternal salvation. Furthermore, as Constantine argued, he achieved this liberation with the aid of the One God, the Creator and Father of all, the Lord and Father of all and God of all, with His might as an

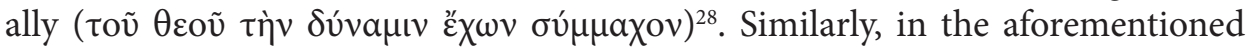

\footnotetext{
${ }^{23}$ Eusebius, Vita Constantini, III, 12, 2, p. 87.

${ }^{24}$ These were mentioned by Eusebius in Vita Constantini (I, 46).

${ }^{25}$ Constantinus Imperator, Oratio ad sanctorum coetum Constantini imperatoris oratio ad coetum sanctorum, 22, [in:] Eusebius, Werke, vol. I, ed. J.A. HeIKEL, Leipzig 1902.

${ }^{26}$ Epistula Constantini imperatoris ad Alexandrum Alexandrinum et Arium, [in:] EusebIus, Vita Constantini, II, 64-66, ed. F. Winkelmann..., p. 74.

${ }^{27}$ Its authenticity was questioned, but Constantine's preparations for a war with Persia are also confirmed in Aphraates' homilies; cf. The Homilies of Aphraates, vol. I, trans. W. Wright, London 1869, passim; Aphraatis Sapientis Persae Demonstationes, vol. I-II, ed. R. PARIsot, Paris 1894-1907 [= PS], passim; cf. T.D. BARNES, Constantine and the Christians of Persia, JRS 75, 1985, p. 126-136. M.R. VIVIAN, Eusebius and Constantine's Letter to Shapur - its Place in the Vita Constantini, [in:] SP 29, 1997, p. 164-169; P.J. Leithart, Defending Constantine. The Twilight of an Empire and the Dawn of Christendom, Downers Grove 2010, p. 45-47; J. Bardill, Constantine, Divine Emperor of the Christian Golden Age, Cambridge 2011, p. 303-304.

${ }^{28}$ Epistula Constantini imperatoris ad Saporem regem Persarum, [in:] Eusebius, Vita Constantini, IV, 9, ed. F. Winkelmann..., p. 123.
} 
letter to Alexander and Arius, Constantine was pointing to God, the Saviour of all

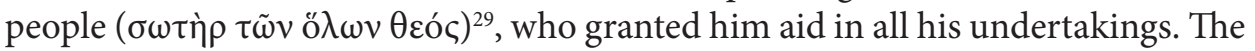
Emperor thus referred not only to the support he received from God in the victorious battles he had to fight, but also to the universal nature of this God, whose care was extended to all the people.

It needs to be pointed out that Constantine linked the activities of tyrants who moved against God with an evil-loving demon, who, having suffered defeat as a result of Constantine's military victories, was, according to the ruler, attempting to insult and curse God's laws by other means, inciting the Arian dispute, which caused a breach within the Church ${ }^{30}$. This the Emperor considered calamitous and more dangerous than any other conflict. The matter of restoring the unity of the Church thus became his main concern. In the lack of unity he saw evil, for which he wanted to find a cure. It was not only the Arian controversy that caused the Emperor's sorrow: he previously became involved in a conflict started by the Donatists in the Carthaginian church. In a letter addressed to the participants of the synod in Arles (in 314), Constantine referred to Donatists as people led astray by the devil's malice and as servants of Satan, who, in turning away from the truth, joined the pagans ${ }^{31}$.

Constantine concretised the evil against which he fought. In his narrative, it took the form of tyrants or the tyranny of those who fought against God, or of a hostile monster who had once besieged the Church through godless tyranny, a mali-

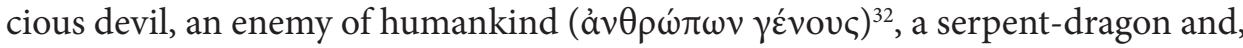
in general, the deceitful Satan. Eusebius of Caesarea, Constantine's biographer, defined it in greater detail in his historical treatise. According to him, the followers

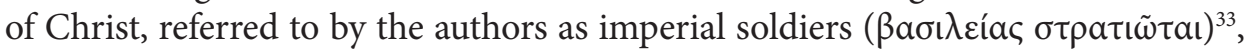

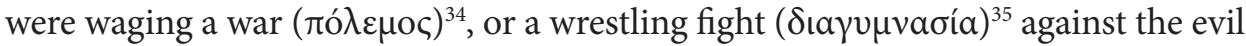

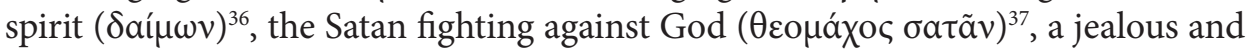

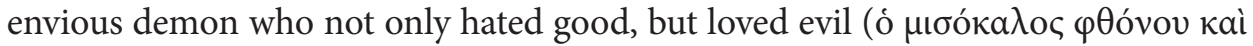

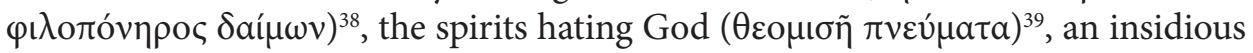

\footnotetext{
${ }^{29}$ Epistula Constantini imperatoris ad Alexandrum Alexandrinum et Arium, [in:] Eusebius, Vita Constantini, II, 64, ed. F. Winkelmann..., p. 74.

${ }^{30}$ Eusebius, Vita Constantini, III, 12.

${ }^{31}$ Epistula Constantini imperatoris ad episcopos scripta post Arelatense concilium, [in:] J.L. MAIER, Le dossier du donatisme, vol. I, Des origines à la mort de Constance II (303-361), Berlin 1987 [= TUGAL], p. 168-171.

${ }^{32}$ Eusebius, Vita Constantini, III, 3.

${ }^{33}$ Eusebius, $H E, \mathrm{X}, 4,15$.

${ }^{34}$ Eusebius, $H E, \mathrm{~V}, 2,6$.

${ }^{35}$ Eusebius, $H E, \mathrm{X}, 4,15$.

${ }^{36}$ Eusebius, $H E$, IV, 7, 10.

${ }^{37}$ Eusebius, HE, VII, 31, 1.

${ }^{38}$ Eusebius, $H E, \mathrm{X}, 4,14 ; \mathrm{X} 8,2$.

${ }^{39}$ Eusebius, HE, X, 4, 13.
} 


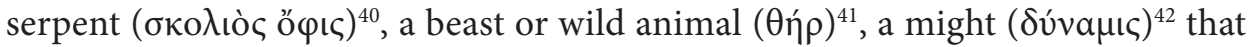
was wicked, vile, malicious and deceptive $\left(\pi \circ \operatorname{lov} \rho{ }^{43}\right)^{43}$, which rejoiced in the mis-

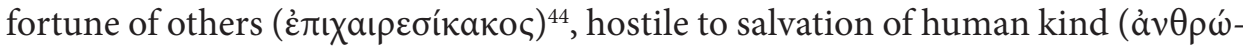

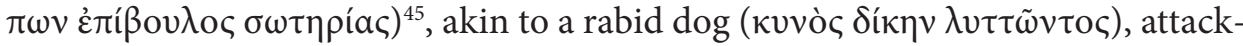
ing in a mad fury, or a hissing serpent oozing deadly venom ${ }^{46}$, a power making use of people overwhelmed with pride $(\varphi \rho o ́ v \eta \mu \alpha)^{47}$, or instigating against Christians all animals and savagery in human form ${ }^{48}$. Therefore, it is clear that Constantine defined the evil against which he fought similarly to Eusebius.

In a letter to the inhabitants of the province of Palestine ${ }^{49}$, the ruler was expressing a conviction that it was God himself who turned him into a remedy for the great godlessness which had taken hold over human kind, and which threatened the Roman Empire with complete destruction. By becoming a tool in God's hands and through His aid, the Emperor, as he thought, banished and completely eliminated all terror and fear which had dominated the world. From now on, human kind, enlightened and instructed by Constantine, was to keep God's holy laws, and the faith was to spread with no obstacles ${ }^{50}$. In another letter, addressed to Eusebius, the Bishop of Caesarea, Constantine was writing about the restoration of freedom, banishing the "serpent" ( $\delta \rho \alpha ́ \kappa \omega v)$ and removing him from administrating public affairs, which was to be effected by the will of the Providence of the Highest God, acting through Constantine ${ }^{51}$. Therefore, on the one hand, he symbolically identified the rivals to power in the Empire whom he had overthrown with evil, and on the other he painted himself as the executor of God's will, ascribing the victories he had attained to Him.

The symbol of a serpent is also present on the coins minted in Constantinople in 327 in commemoration of the city's founding. They depicted the labarum decorated with three medallions with the likenesses of Constantine and his two

\footnotetext{
${ }^{40}$ Eusebius, $H E, \mathrm{~V}, 1,42$.

${ }^{41}$ Eusebius, $H E, \mathrm{~V}, 2,6$.

${ }^{42}$ Eusebius, HE, II, 14, 1.

${ }^{43}$ Eusebius, HE, II, 14, 1.

${ }^{44}$ Eusebius, $H E$, IV, 7, 10.

${ }^{45}$ Eusebius, HE, II, 14, 1.

${ }^{46}$ Eusebius, $H E, \mathrm{X}, 4,14$.

${ }^{47}$ Eusebius, $H E$, I, 2, 19.

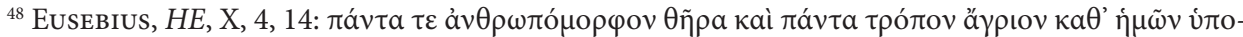

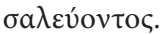

${ }^{49}$ Eusebius, Vita Constantini, II, 24-42.

${ }^{50}$ Eusebius, Vita Constantini, II, 28. According to Noel LeNski (Constantine and the Cities..., p. 50) in his theological pronouncements on the Christian god, Constantine regularly describes the Father and above all Christ as the creator and restorer of light in the world. In many of these same, Constantine portrays himself not just as harbinger of divine light but also as an active agent in its spread, working to guarantee that the darkness of theological error should be banished by the light of truth.

${ }^{51}$ Epistula Constantini imperatoris ad Eusebium, [in:] Eusebius, Vita Constantini, II, 46, 2, ed. F. WiNKELMANN..., p. 67.
} 
sons, Constantius II and Constantine II, its spar embedded in a writhing snake ${ }^{52}$. In a similar manner, the idea of an Emperor vanquishing evil in the form of a serpent-dragon was depicted in an image visible by the front gate leading to the imperial palace. It showed Constantine with his sons, the sign of salvation over

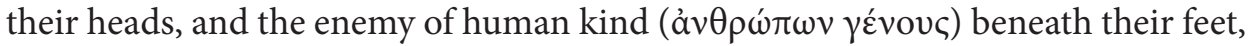
a hostile monster which had once besieged the Church by means of godless tyranny. The creature had the form of a serpent-dragon which was pierced by an arrow and was tumbling into the abyss ${ }^{53}$. Describing this image, Eusebius of Caesarea found an analogy with a prophecy of Isaiah, according to which a writhing dragon, an enemy of God, shall meet its death by the will of God ${ }^{54}$.

As can be seen, in Constantine's own perception, his fight against evil had two underlying dimensions: military and religious. The first of these was related to the ideology of victory and choosing the God of Christians for the divine Patron. At the same time, Constantine's enemies were identified as the enemies of God Himself, and therefore personified evil, or were tools in the hands of demons. Religiously motivated persecution of Christians during the first two decades of the fourth century contributed towards defining said enemies in such a way, as did ascribing Constantine's victories to the Highest, One God, and resulted in treating deities worshipped in the traditional cults as personifying evil demons. The other, religious dimension related to the unity of the cult, indispensable for ensuring the efficacy of the prayers raised towards Heavens and for the Empire's prosperity. This dimension came down to efforts aimed at preserving the unity of the Church, constantly threatened by Satan, who, having been thwarted on the field of battle, attempted to make up for the military defeat in the sphere of the Church, tearing apart the community of the believers. The Emperor felt obliged to take up a comprehensive fight against evil, and therefore, in both the military and religious fields, was intensively seeking the restoration of the unity of the Church. Peace in the military dimension, which put an end to a period of social unrest, oppression and bloodshed, thus restoring the sense of security in the existential and material spheres, was a vital fruit of the victory over evil. In the religious dimension, in its turn, peace brought accords and social harmony, and, first and foremost, the unity of the cult, and therefore the unity of the Church, which resulted in the sense of security among the masses of believers.

In conclusion, it would appear that Emperor Constantine the Great saw in his reign a fundamental change not only in the history of the Imperium Romanum, but also of the entire world. This change had an eschatological dimension. Constantine's reign, at least in its propagandist framing, was to be the turning point

\footnotetext{
52 J. Williams, Religion and Roman Coins, [in:] A Companion to Roman Religion, ed. J. RüPke, London 2007, p. 159.

${ }^{53}$ Eusebius, Vita Constantini, III, 3.

${ }^{54}$ Is 27, 1; Eusebius, Vita Constantini, III, 3, 3.
} 
in the fight against evil. It appears that the ruler was fully aware that by putting an end to the persecutions of Christians he restored universal peace. Thus, the shift with which he is associated amounted to, on the one hand, restoring the pax Christiana and the beginning of the Kingdom of God on earth, and on the other to eliminating evil from the world. Therefore, Constantine, in believing that he had become God's tool for fighting evil, must have also been convinced that he played an incredibly important role in God's plan of salvation, especially since the Kingdom of God, apparently realised on earth through Constantine's military victories, was to only finally prevail when evil and death had been defeated forever.

\section{Bibliography}

\section{Primary Sources}

Acta Conciliorum Oecumenicorum, ed. E. Schwartz, vol. I, Concilium Universale Ephesenum, vol. II, Concilium Universale Chalcedonense, Berolini-Lipsiae 1927-1936.

Ammianus Marcellinus, Rerum gestarum libri qui supersunt, vol. I-II, ed. C.V. Clark, Berlin 1910-1915.

Aphraatis Sapientis Persae Demonstationes, vol. I-II, ed. R. PARIsot, Paris 1894-1907 [= Patrologia syriaca].

Constantinus Imperator, Oratio ad sanctorum coetum Constantini imperatoris oratio ad coetum sanctorum, [in:] Eusebius, Werke, vol. I, ed. J.A. HeikeL, Leipzig 1902, p. 149-192.

Epistula Constantini imperatoris ad Alexandrum Alexandrinum et Arium, [in:] Eusebius, Vita Constantini, ed. F. Winkelmann, Berlin-New York 2008, p. 74-79.

Epistula Constantini imperatoris ad episcopos scripta post Arelatense concilium, [in:] J.L. MAIER, Le dossier du donatisme, vol. I, Des origines à la mort de Constance II (303-361), Berlin 1987

[= Texte und Untersuchungen zur Geschichte der altchristlichen Literatur], p. 168-171.

Epistula Constantini imperatoris ad episcopos (syriace), [in:] Athanasius, Werke, vol. III, ed. H.G. von OpITz, Leipzig-Berlin 1934, p. 41-42.

Epistula Constantini imperatoris ad Eusebium, [in:] Eusebius, Vita Constantini, ed. F. Winkelmann, Berlin-New York 2008.

Epistula Constantini imperatoris ad Saporem regem Persarum, [in:] EusebIus, Vita Constantini, ed. F. Winkelmann, Berlin-New York 2008, p. 123-125.

Eusèbe de CÉSArée, La préparation évangélique, vol. I-IV, ed. et trans. E. Des Places, Paris 1976-1987.

Eusebius, Chronicon, [in:] Eusebius, Werke, vol. VII, Die Chronik des Hieronymus, ed. R. Helm, Berlin 1956 [= Die griechischen christlichen Schriftsteller der ersten [drei] Jahrhunderte, 47].

Eusebius, Demonstratio evangelica, ed. I.A. HeIKel, Leipzig 1913 [= Die griechischen christlichen Schriftsteller der ersten [drei] Jahrhunderte, 23].

Eusebius, Vita Constantini, ed. F. Winkelmann, Berlin-New York 2008.

Euzebiusz z Cezarei, Historia kościelna, trans. A. Caba, ed. H. Pietras, Kraków 2013. 
Lactance, Institutions Divines. Livre V, vol. I-II, ed. et trans. P. Monat, Paris 1973 [= Sources chrétiennes, 204-205].

Origenes, Contra Celsum, ed. M. Marcovich, Leiden 2001.

Orose, Histoires (Contre les Païens), vol. I-II, ed. et trans. M.-P. Arnaud-Lindet, Paris 1990-1991.

Paulinus Nolanus, Epistulae, ed. G. De Hartel, Wien 1894 [= Corpus scriptorum ecclesiasticorum latinorum].

Socrates, Kirchengeschichte, ed. G.C. Hansen, Berlin 1995.

Sozomenus, Kirchengeschichte, ed. J. Bidez, G.C. Hansen, Berlin 1995.

The Homilies of Aphraates, vol. I, trans. W. Wright, London 1869.

\section{Secondary Literature}

Bardill J., Constantine, Divine Emperor of the Christian Golden Age, Cambridge 2011.

Barnes T.D., Christians and Pagans in the Reign of Constantius, [in:] L'Église et l'Empire au IV siècle, ed. A. Dihle, Genève 1989, p. 301-337.

BARnes T.D., Constantine and the Christians of Persia, "Journal of Roman Studies" 75, 1985, p. 126-136.

BARnes T.D., Constantine and Eusebius, Cambridge Mass.-London 1981.

BLEICKen J., Constantin der Grosse und die Christen. Überlegungen zur konstantinischen Wende, München 1992.

Bonamente G., La „svolta constantiniana”, [in:] Cristianesimo e istituzioni politiche. Da Augusto a Guistiniano, ed. E. Dal Covolo, R. Uglione, Roma 2001, p. 147-170.

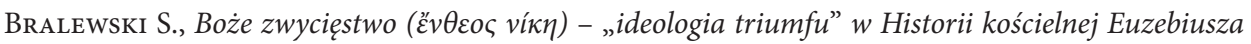
$z$ Cezarei, "Vox Patrum. Antyk Chrześcijański" 35, 2015, p. 333-351.

Bralewski S., Constantinian Shift - the Truth or a Myth, "Vox Patrum. Antyk Chrześcijański" 34, 2014, p. 39-53.

Bralewski S., Przełom konstantyński a religijność Rzymian w wiekach IV i V - wybrane zagadnienia, [in:] Bitwa przy moście mulwijskim. Konsekwencje, ed. Z. Kalinowski, D. PróchniaK, Poznań 2013, p. 115-149.

Bralewski S., Symmachia Cesarstwa Rzymskiego z Bogiem chrześcijan (IV-VI wiek), vol. I, „Niezwykła przemiana" - narodziny nowej epoki, vol. II, Jedna religia w jednym cesarstwie. Rzymscy imperatorzy sprzymierzeni z Bogiem na straży jedności Kościoła od Konstantyna I do Justyniana I, Łódź 2018 [= Byzantina Lodziensia, 27; 32].

Brown P., The World of Late Antiquity, London 1971.

Buchneit V., Goldene Zeit und Paradies auf Erden (Laktanz, Inst. 5,5-8), "Würzburger Jahrbücher für die Altertumswissenschaft” 4, 1978, p. 161-185 and 5, 1979, p. 219-235.

Carlà F., CAStello M.G., Questioni tardoantiche. Storia e mito della svolta costantiniana, Roma 2010.

Elliott T.G., Constantine's Conversion: Do We Really Need It?, "Phoenix. Journal of the Classical Association of Canada / Revue de la Société canadienne des études classiques" 41, 1987, p. $420-438$.

Farina R., Eusebio di Cesarea e la „Svolta Costantiniana”, “Augustinianum. Periodicum semestre Instituti Patristici" 26, 1986, p. 313-322.

Frend W.H.C., Martyrdom and Persecution in the Early Church. A Study of a Conflict from the Maccabees to Donatus, Oxford 1965. 
Girardet K.M., Die Konstantinische Wende. Voraussetzungen und geistige Grundlagen der Religionspolitik Konstantins des Grossen, Darmstadt 2006.

ILsKi K., Idea jedności politycznej społecznej i religijnej w świetle pism Ambrożego z Mediolanu, Poznań 2001.

Die Kirche Angesichts der Konstantinischen Wende, ed. G. Ruнbach, Darmstadt 1976.

Konstantin der Grosse. Kaiser einer Epochenwende, ed. F. Schuller, H. Wolff, München 2007.

Die konstantinische Wende, ed. E. MüCHLEnBERG, Gütersloh 1998.

KotŁowska A., Obraz dziejów w Chronici Canones Euzebiusza z Cezarei, Poznań 2009.

Kühschelm R., Nowy Testament, [in:] K. Koenen, R. KüHschelm, Przełom czasów z perspektywy Starego i Nowego Testamentu, trans. J. Zychowicz, Kraków 2001, p. 83-159.

Lançon B., Moreau T., Constantin. Un Auguste chrétien, Paris 2012.

Leithart P.J., Defending Constantine. The Twilight of an Empire and the Dawn of Christendom, Downers Grove 2010.

Lenski N., Constantine and the Cities. Imperial Authority and Civic Politics, Philadelphia 2016.

Millar F., The Emperor in the Roman World 31 B.C.-A.D. 337, London 1977.

NaWracaŁa T., Gdzie jest basileia? Biblijne, historyczne i teologiczne aspekty współczesnej dyskusji na temat królestwa Bożego, "Poznańskie Studia Teologiczne" 25, 2011, p. 174-182.

Nicholson O., Golden Age and the End of the World: Myths of Mediterranean Life from Lactantius to Joshua the Stylite, [in:] The Mediaeval Mediterranean, ed. M. Chiat, K. Reyerson, S. Cloud, Minnesota 1989, p. 11-18.

Pietras H., Sobór Nicejski (325). Kontekst religijny i polityczny, dokumenty, komentarze, Kraków 2013.

Le problème de la christianisation du monde antique, ed. H. Inglebert, S. Destephen, B. DuméziL, Paris 2010.

RIst J., Constantin et l'Église. Remarques sur le soi-disant tournant constantinien, "Connaissance des Pères de l'Église" 109, 2008, p. 43-55.

Swift L.J., Lactantius and the Golden Age, "American Journal of Philology" 89, 1968, p. 144-156.

VAN DAM R., The Roman Revolution of Constantine, Cambridge 2007.

Vivian M.R., Eusebius and Constantine's Letter to Shapur - its Place in the Vita Constantini, [in:] Studia patristica 29, 1997, p. 164-169.

Vogt J., Die Revolution Constantins des Grossen, [in:] Constantin der Grosse und sein Jahrhundert, München 1960, p. 135-256.

Wallraf M., Christus Verus Sol. Sonnenverehrung und Christentum in der Spätantike, Münster 2001.

Williams J., Religion and Roman Coins, [in:] A Companion to Roman Religion, ed. J. RüPke, London 2007, p. 143-163. 


\begin{abstract}
In this article, I try to answer the following question: was Constantine himself aware of the revolution that he was carrying out? Did he realise that his actions were going to change the course of the history of the Empire? An analysis of sources seems to indicate that emperor Constantine the Great saw in his reign a fundamental change not only in the history of the Imperium Romanum, but also of the entire world. He believed that this change had an eschatological dimension. Constantine's reign, at least in its propagandist framing, was to be the turning point in the fight against evil. It appears that the ruler was fully aware that by putting an end to the persecutions of Christians he was restoring universal peace. Thus, the shift with which he is associated amounted, on the one hand, to restoring the pax Christiana and the beginning of the Kingdom of God on earth, and on the other to eliminating evil from the world. Therefore, Constantine, in believing that he had become God's tool for fighting evil, must have also been convinced that he played an incredibly important role in God's plan of salvation; especially since the Kingdom of God, apparently realised on earth through Constantine's military victories, was to only finally prevail when evil and death had been defeated forever.
\end{abstract}

Keywords: emperor Constantine the Great, Constantinian shift, Late Roman Empire.

\title{
Sławomir Bralewski
}

University of Łódź

Faculty of Philosophy and History

Department of Byzantine History

ul. Kamińskiego 27a

90-219 Łódź, Poland

slawomir.bralewski@gmail.com 